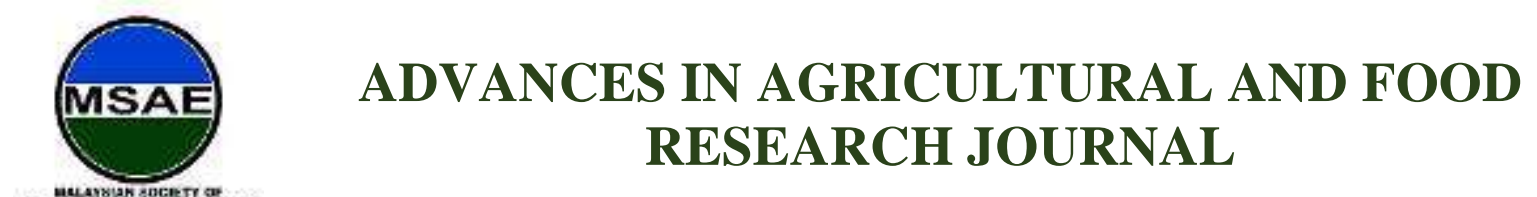

HH PUBLISHER

Product Development

\title{
Preliminary Study of Pineapple Pruning Machine for Pineapple Suckers Production
}

\begin{abstract}
Adli Fikri Ahmad Sayuti ${ }^{1 *}$, Rohazrin Abdul Rani², and Nurul Ahmad Sayuti ${ }^{3}$
${ }^{1}$ Engineering Research Centre, Malaysia Agriculture Research and Development Institute, Serdang, 43000 Selangor, Malaysia, adlifikri@mardi.gov.my

${ }^{2}$ Engineering Research Centre, Malaysia Agriculture Research and Development Institute, Serdang, 43000 Selangor, Malaysia, rohazrin@mardi.gov.my

${ }^{3}$ Department of Veterinary Pathology \& Microbiology, Faculty of Veterinary Medicine, Universiti Putra Malaysia, 43400 UPM, Serdang, Selangor Darul Ehsan, Malaysia. Nurulsyahirah0806@gmail.com

*Corresponding author: Adli Fikri Ahmad Sayuti, Engineering Research Centre, Malaysia Agriculture Research and Development Institute, Serdang, 43000 Selangor, Malaysia; adlifikri@ mardi.gov.my
\end{abstract}

\begin{abstract}
In 11th Malaysia plan (RMK-11) a new concept and prototype were developed with a two-blade disc type, powered by a gearbox 1:3 ratio and adjustable height for peat soil condition. After the pineapple crop has reached the age of 15 months, it will be harvested and pruned before fertilizer application work for pineapple sucker production begins. Normally under conventional method, farmers will use a sharp machete or sickle to prune. However, pineapple leaves and cob have high fibres content which can cause pineapple crops to break easily. The conventional method requires a lot of time as well as the need for a large labour force, and the cost of production would also increase in this regard. The objective of the study was to evaluate the performance and effectiveness of using a mechanization approach in comparison to the conventional method in pruning of the pineapple crop. A 38hp tractor with high clearance rubber trek powered by power take off (PTO) max speed 540 and tractor rpm 1500 was used in this research. The height of the cutter blade can be adjustable according to the height of the crop needed to be pruned. The capable working rate of the machine was 0.86 ha/hour, speed tractor was $2.03 \mathrm{~km} /$ hour Machined time operation was up to $1.2 \mathrm{hour} / \mathrm{ha}$ and operated for 8.4 ha/per-day. Additionally, the machine seems have a clean-cut result on pineapple leaves and cob without breaking the pineapple crop.
\end{abstract}

Keywords: Pineapple pruning machine; conventional; pineapple crop; prune

Received: $29^{\text {th }}$ March 2021

Received in revised form: $18^{\text {th }}$ June 2021

Accepted: $26^{\text {th }}$ June 2021

Available Online: $2^{\text {nd }}$ July 2021
Citation: Ahmad Sayuti, AF, Abdul Rani R, Ahmad Sayuti N. Preliminary study of pineapple pruning machine for pineapple suckers production. Adv Agri Food Res J 2021; 2(2): a0000208. https://doi.org/10.36877/aafrj.a0000208 


\section{Introduction}

As an export commodity that contributes to Gross Domestic Product (KDNK), pineapple (Ananas comosus) has been an important tropical fruit crop in our country since 1900. The Malaysian pineapple industry board (LPNM) estimated that the physical cultivation of pineapple in Malaysia covered 15,774 hectares with a harvested area of approximately 13,148 hectares, which produced 391,714 metric tons of pineapple with a production value of around RM515.248 million in 2016 (Lembaga Perindustrian Nanas, 2017). With this estimate, the pineapple industry needs a lot of suckers with the seed requirement rate of 17,000 suckers per acre (or 42,000 seed suckers per hectare) per planting. If calculated with simple numbers on crop area then as many as 662.5 million pineapple crops were planted in 2016 in stages.

If the planting of Moris and MD2 pineapples and some other varieties is carried out in stages for 12-14 months, then the need for pineapple suckers in the country will be about 50-55 million a month (Anim, 2017).

After the pineapple crop is 1 year 3 months old, the pineapple will be harvested and the pruning process will be done before fertilization work begin. Normally under conventional method, farmers use a sharp machete or sickle to prune the leaves but because pineapple leaves and cob have a high fibre content, this action causes the leaves and cob to break easily. Additionally, the conventional method requires a lot of time as well as the need for a large labour force that would drive up the cost of production in this regard. In 10th Malaysian plan (RMK-10), MARDI has come out with a machine that can prune and cut the pineapple crop which were a practice in mineral soil. This machine is adopts the concept of a lawn mower that has a horizontal shaped blade pointed with a strong swing force. Unfortunately, the result of the cut by the machine was seen breaking the pineapple cob and leaves. In order to overcome this challenge, a new design and prototype were developed in the 11th Malaysia plan (RMK-11) (Adli Fikri \& Rohazrin, 2020).

\section{Materials and Methods}

\subsection{Machine Design}

A new conceptual design and prototype of a pruning machine was developed in the $11^{\text {th }}$ Malaysia Plan (RMK-11) consisting of two circular blade discs with 16 diameter widths, powered by a gearbox ratio of $1: 3$ as a power converter with the capability of providing highspeed rpm clockwise rotation between 1600-1620 rpm and an adjustable height for blade and machine cutting as shown in Figure 2. The technical design specification is shown in Figure 1 and Table 1. This machine is capable of working under the conditions of mineral and peat soil. This machine is then connected to a high-clearance $38 \mathrm{hp}$ rubber trek tractor powered by PTO max speed 540 and tractor rpm 1500. As shown in Figure 3, the tractor with the 
integrated machine was capable of entering the pineapple plantation and performs pruning work in the field.

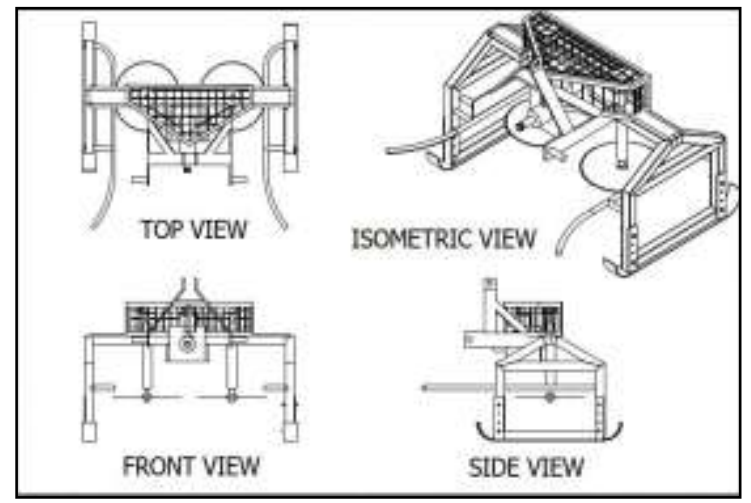

Figure 1. Technical drawing of the pineapple pruning machine design.

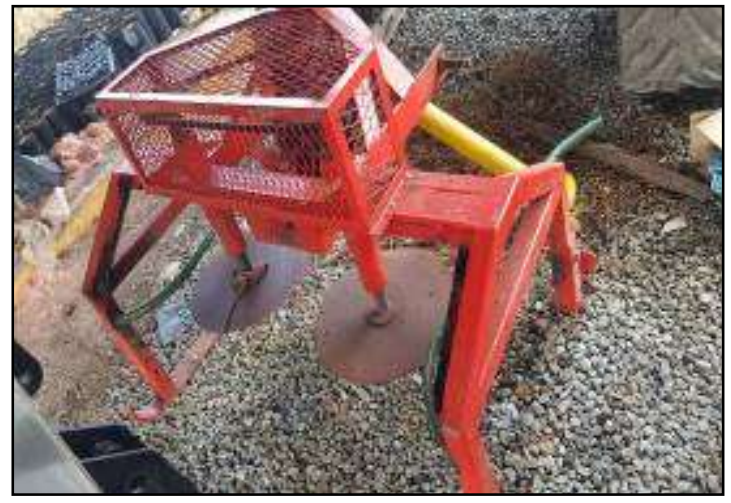

Figure 2. Final prototype of the pineapple pruning machine

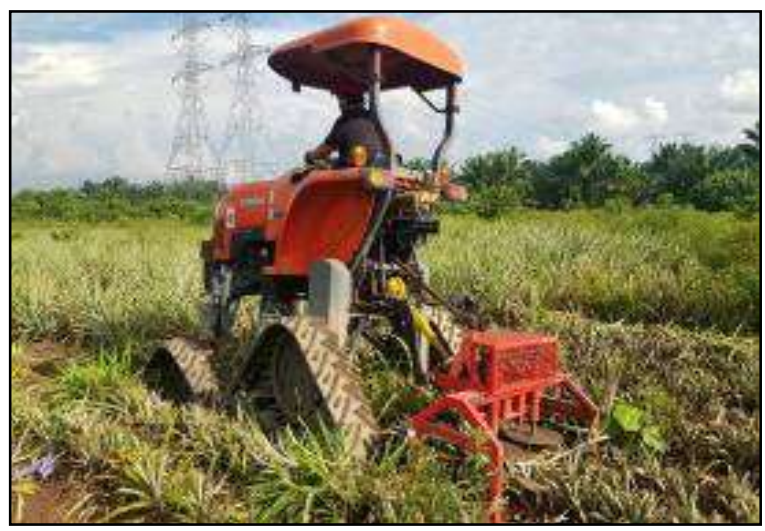

Figure 3. Tractor integrated with the pineapple pruning machine.

Table 1. Technical design specification.

\begin{tabular}{cc}
\hline Parameter & Value \\
\hline Length & $1200 \mathrm{~mm}$ \\
Width & $500 \mathrm{~mm}$ \\
Height & $1128 \mathrm{~mm}$ \\
Frame & Hollow steel 3" x 2" Carbon steel \\
& Thickness 3mm \\
Gearbox/ Transmission & $1: 3$ ratio/ 3-way maximum output \\
& (4500-6000 rpm) \\
Type of cutter & 2-unit Circular saw 16" \\
& Diameter 254mm x 80 teeth \\
\hline
\end{tabular}




\subsection{Performance and Evaluation Test}

The machine prototype was tested and evaluated at MARDI Pontian, Johor as shown in Figure 4. The machine prototype was integrated to a tractor and driven with two different speed rates of $1.87 \mathrm{~km} /$ hour and $2.03 \mathrm{~km} /$ hour with $3^{\text {rd }}$ gear low and $4^{\text {th }}$ gear low, respectively. The speed of the PTO was $540 \mathrm{rpm}$ driven using the same fixed $1500 \mathrm{rpm}$ tractor speed for both of the gears. These two speed rates were chosen because they were the most popularly used in land preparation activities such as rotovator and ploughing. An experimental plot distance of $12 \mathrm{~m} \times 9 \mathrm{~m}$ with six replicates (L1, L2, L3, L4, L5, and L6) and a total area of 0.010 hectares as shown in Figure 5 was used in the study and the time taken for pruning between the two different gears were recorded for analysis. The main objective was to ensure that the pineapple crop was cut through the middle with $30 \mathrm{~cm}$ height from the land surface using the two different gears but with the same PTO speed. The result of the height was also measured and analysed.

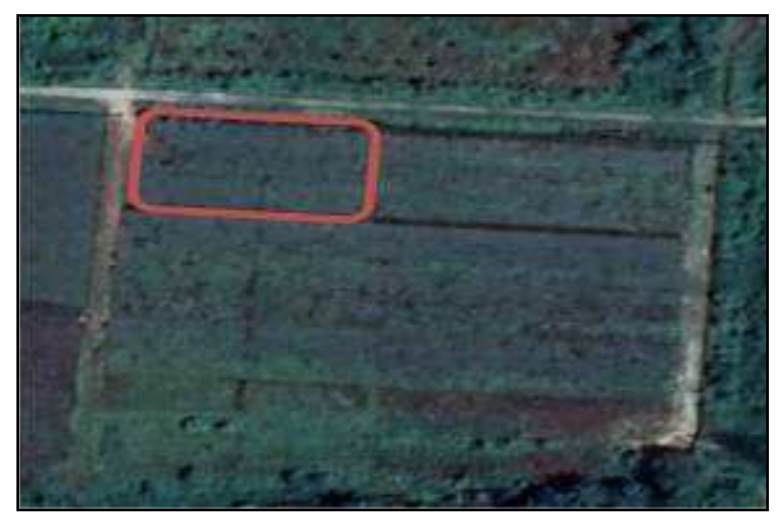

Figure 4. Pineapple testing plot MARDI Pontian, Johor.

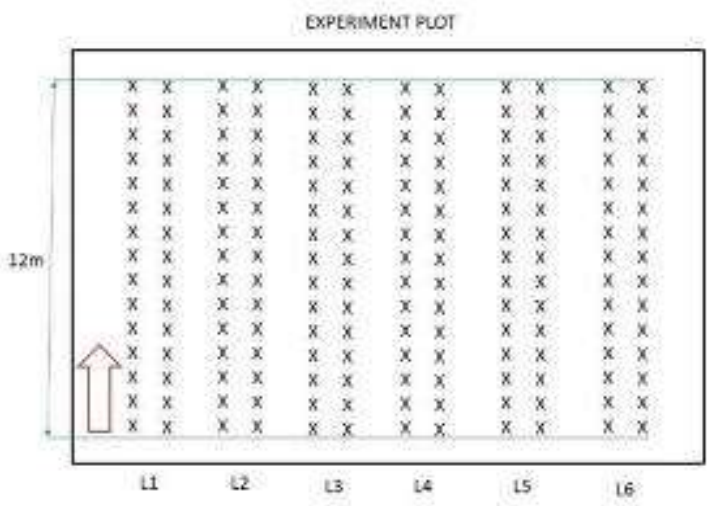

Figure 5. Experimental plot.

\subsection{Conventional Method}

As for the conventional method, a sharp machete and sickle were used by farmers to prune pineapple crop that have been harvested to heights of $30-40 \mathrm{~cm}$ before spraying with urea fertilizer using foliar spraying method as shown in Figure 6. This method of study was also conducted at the pineapple plot at MARDI, Pontian, Johor with an area of $12 \mathrm{~m} \times 6 \mathrm{~m}$ (L1A, L1B, L2A and L2B) as shown in Figure 7. For this experiment, it was divided into 3 subplots, namely the beginning, middle and end stage where the aim was to study the consistency of workers' energy ability to prune a crop without having to stop for a $12 \mathrm{~m}$ length and measure whether the height of the pineapple crop was trimmed uniformly or formally. 


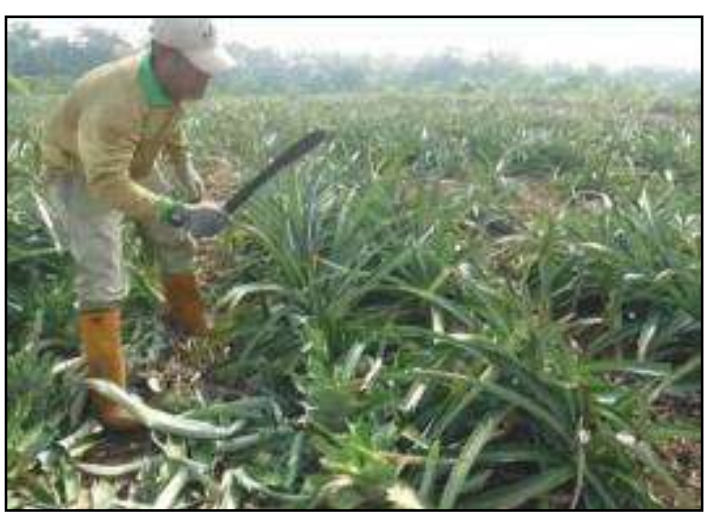

Figure 6. Conventional method.

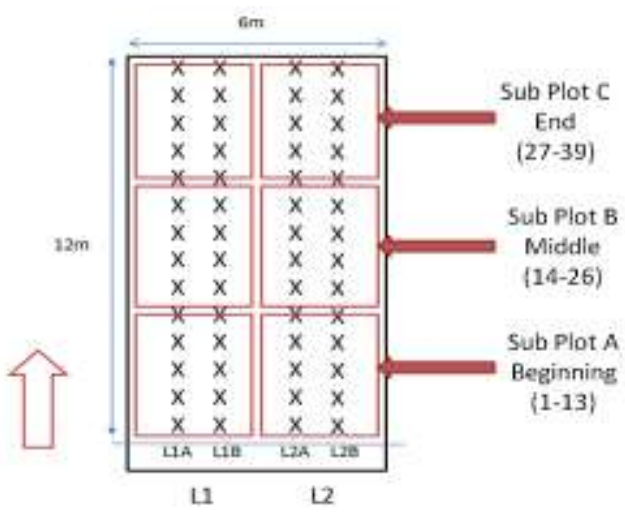

Figure 7. Experiment layout for conventional method.

\section{Results}

\subsection{Data and Analysis Using Two Different Speed Rates}

Data collection from performance evaluation testing is shown in Table 2 using two different gear tractors. The results demonstrated that a gap of $0.02 \mathrm{ha} / \mathrm{hr}$ for work rate, 0.16 $\mathrm{km} / \mathrm{hr}$ for speed of tractor and $0.9 \mathrm{hr} / \mathrm{ha}$ were observed between the two gear speed rates. In the t-test analysis of the comparison of speed and height of the crop after pruning, insignificant values $(p>0.05)$ of height differences were observed between the two different speed rate as shown in Table 3. This shows that despite using different speeds, the height of the crop is the same and is formally shown in Table 3 . The pruning results obtained was clean-cut with a uniform height as shown in Figure 8.

Table 2. The summary of results performance evaluation.

\begin{tabular}{|c|c|c|c|c|c|c|}
\hline No. Row & L1 & $\mathbf{L 2}$ & $\mathbf{L 3}$ & L4 & L5 & L6 \\
\hline Parameter & \multicolumn{3}{|c|}{$\begin{array}{c}\text { Rpm } 1500 \text { Gear } 3 \\
\text { Low }\end{array}$} & \multicolumn{3}{|c|}{$\begin{array}{c}\text { Rpm } 1500 \text { Gear } \\
4 \text { Low }\end{array}$} \\
\hline Work-rate (ha/hr) & \multicolumn{3}{|c|}{ 0.28(Average) } & \multicolumn{3}{|c|}{0.3 (Average) } \\
\hline Tractor-speed $(\mathrm{km} / \mathrm{hr})$ & \multicolumn{3}{|c|}{1.87} & \multicolumn{3}{|c|}{2.03} \\
\hline $\begin{array}{l}\text { Operation-time } \\
\text { (hr/ha) }\end{array}$ & \multicolumn{3}{|c|}{2.1} & \multicolumn{3}{|c|}{1.2} \\
\hline
\end{tabular}


Table 3. The summary of results performance evaluation and data analysis using t-test.

\begin{tabular}{|c|c|c|c|c|c|c|}
\hline \multicolumn{7}{|c|}{ One-Sample Test } \\
\hline & \multicolumn{6}{|c|}{ Test Value $=0$} \\
\hline & \multirow[t]{2}{*}{$\mathbf{t}$} & \multirow[t]{2}{*}{ df } & \multirow[t]{2}{*}{ Sig. (2-tailed) } & \multirow[t]{2}{*}{$\begin{array}{c}\text { Mean } \\
\text { Difference }\end{array}$} & \multicolumn{2}{|c|}{$\begin{array}{l}\text { 95\% Confidence Interval of the } \\
\text { Difference }\end{array}$} \\
\hline & & & & & Lower & Upper \\
\hline speed1 & 310.485 & 233 & .000 & 28.12692 & 27.9484 & 28.3054 \\
\hline speed2 & 367.364 & 233 & .000 & 28.68077 & 28.5270 & 28.8346 \\
\hline \multicolumn{3}{|c|}{ Speed } & \multicolumn{3}{|c|}{ Height $(\mathrm{cm})($ mean \pm SD $)$} & Significant \\
\hline \multicolumn{3}{|c|}{1.87 km/hr (L1, L2, L3) } & \multicolumn{2}{|c|}{$28.13 \pm 1.39$} & \multirow{2}{*}{\multicolumn{2}{|c|}{0.940}} \\
\hline \multicolumn{3}{|c|}{$2.03 \mathrm{~km} / \mathrm{hr}(\mathrm{L} 4, \mathrm{~L} 5, \mathrm{~L} 6)$} & \multicolumn{2}{|c|}{$28.68 \pm 1.19$} & & \\
\hline
\end{tabular}

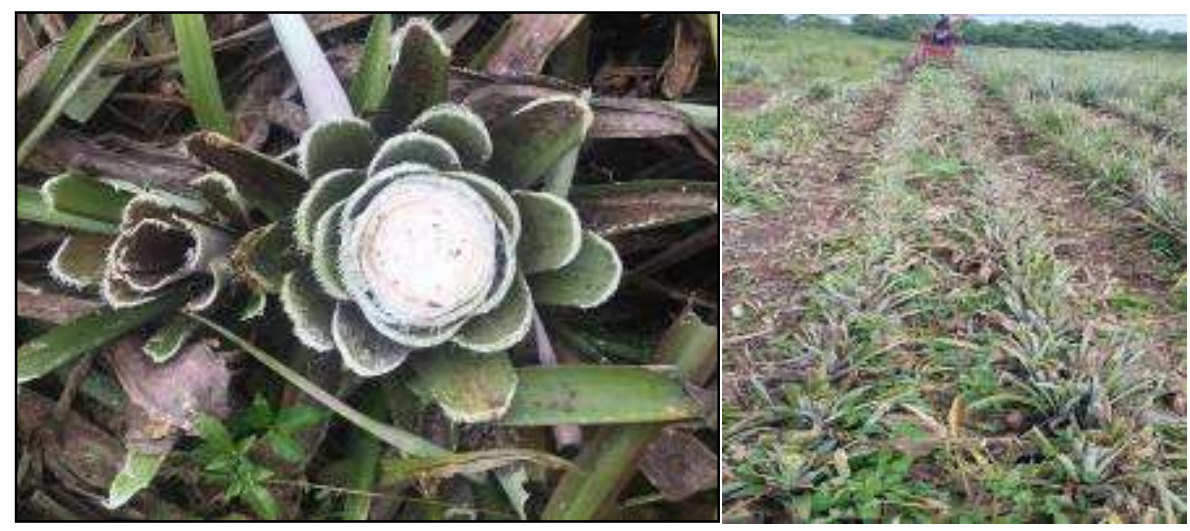

Figure 8. Result of clean-cut and uniform height.

\subsection{Data and Analysis for Conventional Method}

Table 4 shows the result obtained from the conventional method experiment based on the consistency workers' energy ability using an Anova test. Different superscript on the same line shows significant data $(p<0.05)$ for lanes L1A and L1B for all the cuts (beginning, middle and end). However, for lanes L2A and L2B, only the initial deduction showed significant $(p<0.05)$ while the sum of the intermediate and final deductions for both lanes were seen as insignificant as shown in Table 4 and Figure 9.

Table 4. The summary of results conventional method and data analysis using Anova-test.

\begin{tabular}{cccc}
\hline Lanes & $\begin{array}{c}\text { (A) } \\
\text { Sum of cutting for } \\
\text { Beginning (Mean } \pm \\
\text { SEM) }\end{array}$ & $\begin{array}{c}(\text { B) } \\
\text { Sum of cutting for } \\
\text { Middle (Mean } \pm \text { SEM) }\end{array}$ & $\begin{array}{c}\text { (C) } \\
\text { Sum of cutting for End } \\
\text { (Mean } \pm \text { SEM) }\end{array}$ \\
\hline L1A & $61.00 \pm 0.24^{\mathrm{a}}$ & $57.46 \pm 0.56^{\mathrm{b}}$ & $53.67 \pm 0.77^{\mathrm{c}}$ \\
L1B & $61.15 \pm 0.41^{\mathrm{a}}$ & $57.95 \pm 0.55^{\mathrm{b}}$ & $54.09 \pm 0.77^{\mathrm{c}}$ \\
L2A & $62.00 \pm 0.69^{\mathrm{a}}$ & $54.80 \pm 0.60^{\mathrm{b}}$ & $52.72 \pm 0.84^{\mathrm{b}}$ \\
L2B & $60.98 \pm 0.61^{\mathrm{a}}$ & $55.45 \pm 0.42^{\mathrm{b}}$ & $54.04 \pm 1.08^{\mathrm{b}}$ \\
\hline
\end{tabular}




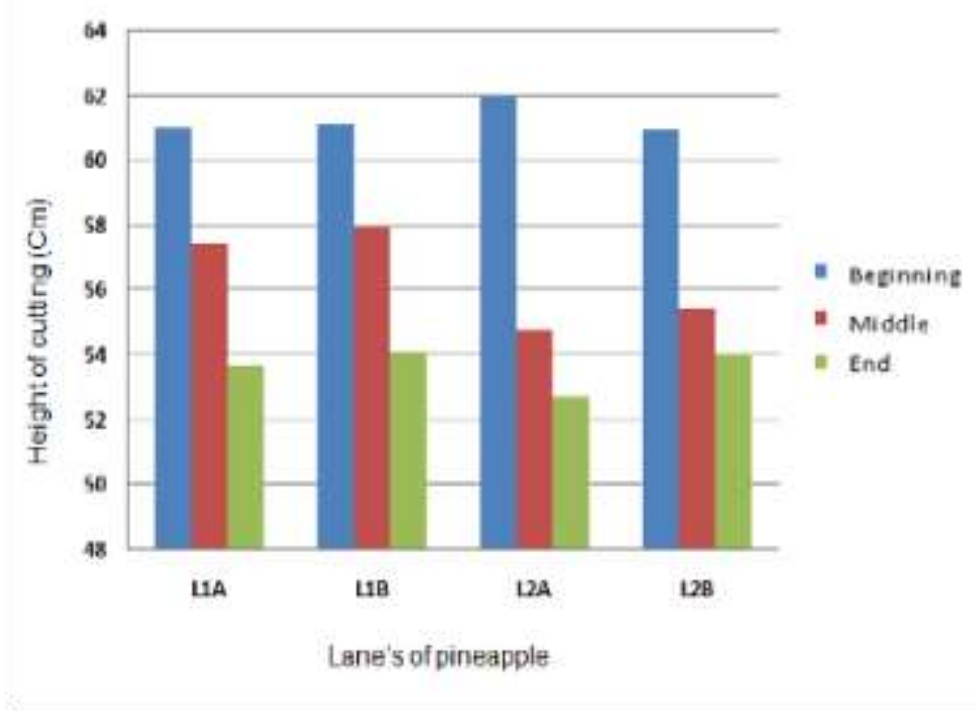

Figure 9. Chart of cutting height results using conventional method based on consistency workers energy ability

\section{Discussion}

Based on the results obtained, it was observed that the machine prototype operated at speed rates of $2.03 \mathrm{~km} / \mathrm{hr}$ and $1.87 \mathrm{~km} / \mathrm{hr}$ does not affect pruning as the machine was able to produce the height that has been set before the operation was carried out, obtaining a cleancut surface with a formally height. The aim of a clean-cut surface and formally height was to use this natural response to effectively curb direct plant growth and establish a desired shape, scale, and/or productivity level for the (Adli Fikri \& Rohazrin, 2020). This was because the same PTO output of $540 \mathrm{rpm}$ connected to the gearbox 1:3 as a speed converter was used in which an effective, good and neat record was obtained. In addition, the use of a speed rate of $2.03 \mathrm{~km} / \mathrm{hr}$ on the $4^{\text {th }}$ gear was seen to be more time-consuming because the operation time taken was 1.2 hectare per-hour, which was seen as ideal for pruning pineapple (Adli Fikri \& Rohazrin, 2020). As for the conventional method, based on the energy capacity of the workers to prune the pineapple crop, there was a pattern of decline and a lack of height uniformity in the pruning results with an oblique angle at the middle and end stages of pruning. This can be seen as a decline in the workers' energy ability from the beginning stage of pruning where the workers were still able to prune easily and eventually having less energy ability towards the middle and the end stages. Based on this result, pruning work requires time and a lot of energy.

\section{Conclusions}

From the studies conducted, we can conclude that different speed rates do not have a differential effect on the height of the pineapple crop, while in terms of saving operation time, the use of a speed rate of $2.03 \mathrm{~km} / \mathrm{ha}$ was able to prune $0.85 \mathrm{ha} / \mathrm{hour}$ while a speed rate of $1.87 \mathrm{~km} / \mathrm{ha}$ can prune $0.47 \mathrm{ha} /$ hour. By using 1 operator only, the work-rate can hit $6.8 \mathrm{ha} /$ day 
compared to the conventional approach of using at least 8-10 employees and one worker can prune as much as $0.125 \mathrm{ha} /$ day, meaning $0.96 \mathrm{ha} /$ day for 10 employees. With the mechanization approach, this work can be done more quickly, economically and uniformly. To the best of our knowledge, there is still no existing machinery in the markets similar to the one presented in this study

Acknowledgments: In this segment, you may acknowledge any support that is not addressed by the author's contribution or funding sections.

Conflicts of Interest: The authors declare no conflict of interest.

\section{References}

Adli Fikri, A. S \& Rohazrin, A. R. (2020). IM8 Pineapple Pruning machine for pineapple suckers production. MARDI Science and Technology Exhibition (MSTE2020).

Anim, M. (2017, September 2). Pemilihan benih nanas. Anim Agro technology. Retrieved from: http://animhosnan.blogspot.com/2017/09/pemilihan-benih-nanas.html

Lembaga Perindustrian Nanas Malaysia (2017). Online Statistic. Retrieved from: http://www.mpib.gov.my/en/online-statistics-2017

Copyright (C) 2021 by Ahmad Sayuti A. F., et al. and HH Publisher. This work is licensed under the Creative 